\title{
HIGH EVAPORATION ON GLACIERS ON THE NORTHWESTERN TIBETAN PLATEAU
}

\section{(Abstract)}

\author{
by
}

Tetsuo Ohata

(Water Research Institute, Nagoya University, Nagoya, Japan)

Shuhei Takahashi

(Kitami Institute of Technology, Kitami, Japan)

and

Hiroyuki Ohno

(Water Research Institute, Nagoya University, Nagoya, Japan)

Quite high amounts of evaporation observed on glaciers in dry Central Asia are one important component in the mass balance of glaciers. During glaciological research at West Kunlun Mountains on the northwestern Tibetan plateau in 1987, high evaporation of more than $2 \mathrm{~mm}$ of water per day was observed near the equilibrium line (5800$5900 \mathrm{~m}$ a.s.1.) in mid-summer due to dry and windy climate. Annual evaporation is estimated by a semi-empirical method using the full year meteorological data taken by an automatic meteorological station. This value shows that evaporation occupies quite a high percentage within the mass balance near the equilibrium line and on the whole glacier. Discussions will centre on comparison with evaporation data obtained on other glaciers and on the effect of such evaporation in the climate-glacier relation.

\section{EXTRACTING CLIMATIC INFORMATION FROM OBSERVATIONS OF ICEBERGS IN THE SOUTHERN OCEAN}

\author{
(Abstract) \\ by \\ Olav Orheim \\ (Norsk Polarinstitutt, P.O. Box 158, 1330 Oslo Lufthavn, Norway)
}

Antarctic iceberg observations provide two types of climatic information: (1) the rate of iceberg calving gives the main negative term in the mass balance of Antarctica; (2) the distribution of icebergs in the Southern Ocean is related to various factors including sea-ice extent and ocean conditions. This paper discusses climatic information obtained both from modern iceberg observations, and from historical data.

The main modern data source is the international iceberg observation programme, initiated in 1981. This has generated a database which now contains observations of size and position of 150000 icebergs in the Southern Ocean. Other recent data sources include observations from 1974 of icebergs of over $22 \mathrm{~km}$ length by the Navy/NOAA Joint Ice Center (which now total nearly 100 bergs). Historical sources include both scientific and commercial (whaling) expeditions.

Three conclusions can be drawn from the recent iceberg data.

(1) For the past seven years annual calving rates of icebergs less than $22 \mathrm{~km}$ in length have been approximately constant both in numbers and total mass, and have exceeded the annual mean mass of bergs over $22 \mathrm{~km}$ calved during the same period.

(2) The annually-calved mass of gigantic icebergs of length over $22 \mathrm{~km}$, has varied more than two orders of magnitude during the past two decades. The mass of calved gigantic icebergs alone exceeded continental snow accumulation in 1967, 1986 and 1987.

(3) Mean iceberg calving rate exceeds continental snow accumulation rate.

These results are discussed in relation to Antarctic mass balance and sea level.

Historical observations of iceberg distributions in the Southern Ocean differ from recent observations by showing: (i) higher frequencies of bergs at lower latitudes, (ii) a larger proportion of large bergs, and (iii) a more uniform iceberg distribution throughout the region. Comparisons between past and present distribution patterns indicate that there must be errors, including exaggerations and selective reporting, in the historical data. Such observations should therefore not be used uncritically to make climatic conclusions.

Bearing in mind the potential flaws in historical data there still appears to be real variations with time in iceberg distribution. These include higher frequencies of bergs at lower latitudes during the past century and the first decades of this century, than at present. Expanded northern range of the bergs would occur if one or more of the following conditions then applied: (1) calved icebergs were larger; (2) sea ice was more extensive in time and space; (3) ocean temperatures were lower; (4) ocean (wind) conditions were such that northward advection rates were higher. The importance of each of these conditions is discussed. 